Article

\title{
Simulation of the Impact of SRT on Anaerobic Digestability of Ultrasonicated Hog Manure
}

\author{
Elsayed Elbeshbishy ${ }^{1}$, Angel Nakevski ${ }^{2}$, Hisham Hafez ${ }^{1}$, Madhumita Ray ${ }^{2}{ }^{*}$ and \\ George Nakhla $^{1,2}$
}

1 Department of Civil and Environmental Engineering, University of Western Ontario, London, Ontario N6A 5B9, Canada; E-Mails: eelbeshb@uwo.ca (E.E.); hhafez@uwo.ca (H.H.); gnakhla@eng.uwo.ca (G.N.)

2 Department of Chemical and Biochemical Engineering, University of Western Ontario, London, Ontario N6A 5B9, Canada; E-Mail: anakevsk@uwo.ca

* Author to whom correspondence should be addressed; E-Mail: mray@eng.uwo.ca; Tel.: +1-519-661-2111-x81273; Fax: +1-519-661-3498.

Received: 26 March 2010 / Accepted: 15 April 2010 / Published: 11 May 2010

\begin{abstract}
Ultrasonication at a specific energy of $500 \mathrm{~kJ} / \mathrm{kgTS}$ was applied to hog manure in a continuous mode completely mixed anaerobic digestion. A process model in BioWin was developed, calibrated and tested at different solids retention times (SRTs) to evaluate the process economics. The results showed that there was a $36 \%$ increase in volatile suspended solids (VSS) removal efficiency, a $20 \%$ increase in methane production rate, a $13.5 \%$ increase in destruction of bound proteins, and a reduction from 988 to $566 \mathrm{ppm}$ in $\mathrm{H}_{2} \mathrm{~S}$ concentration in the digester headspace. Furthermore, a calibrated model of the process using BioWin to assess the impact of SRTs on the economics of anaerobic digestion for unsonicated and sonicated hog manure revealed that ultrasonication resulted in a net benefit of $\$ 42-46 /$ ton dry solids at SRTs of 15-30 days.
\end{abstract}

Keywords: anaerobic digestion; SRT; ultrasound; hog manure; bound protein

\section{Nomenclature}

$\begin{array}{ll}\mathrm{AD} & \text { Anaerobic digestion } \\ \text { B-Protein } & \text { Bound protein } \\ \mathrm{L}_{\mathrm{CH} 4} & \text { Litre of } \mathrm{CH}_{4}\end{array}$




$\begin{array}{ll}\mathrm{L}_{\mathrm{r}} & \text { Litre of reactor } \\ \mathrm{P} & \text { Ultrasonic power } \\ \text { P-Protein } & \text { Particulate protein } \\ \text { SCOD } & \text { Soluble chemical oxygen demand } \\ \text { SE } & \text { Specific energy input } \\ \text { S-Protein } & \text { Soluble protein } \\ \text { SRT } & \text { Solids retention time } \\ \text { SRTs } & \text { Solids retention times } \\ \text { STKN } & \text { Soluble total Kjeldahl nitrogen } \\ \text { t } & \text { Ultrasonic duration } \\ \text { TCOD } & \text { Total chemical oxygen demand } \\ \text { TKN } & \text { Total Kjeldahl nitrogen } \\ \text { TS } & \text { Total solids } \\ \text { TSS } & \text { Total suspended solids } \\ \text { V } & \text { Volume of sonicated manure } \\ \text { VFA } & \text { Volatile fatty acids } \\ \text { VSS } & \text { Volatile suspended solids } \\ \text { WAS } & \text { Waste-activated sludge }\end{array}$

\section{Introduction}

Although swine wastewater is widely used as fertilizer because of its high organic, nitrogen and phosphorus content, many countries are paying attention to the pollution resulting from livestock farms, and have tightened legislation and discharge standards recently. As far as swine waste treatment is concerned, anaerobic digestion (AD) is an important alternative to land application, because it reduces pollution and recovers methane. A number of studies have been reported for anaerobic digestion of swine waste [1-4] in the literature.

In general, the limiting step of anaerobic digestion of solid waste is the first step of hydrolysis or solubilization, where the cell wall is broken down allowing the organic matter inside the cell to be available for biological degradation [5-8]. Particularly, in the case of livestock residues, the hydrolysis step is restricted by the presence of fibres [9]. The anaerobic digestion process may therefore be improved if hydrolysis can be enhanced. Thus, pretreatment is often required in order to achieve the release of lignocellulosic material and thus accelerate the degradation process by means of waste solubilization and consequently enhance the biogas production during anaerobic digestion [9]. Various pretreatment methods such as thermal, chemical, ultrasonic, and biological have been studied by many researchers [10-13]. Since the hydrolysis rate is directly related to the surface area of the sludge particles [14], increasing particles surface area will also increase the hydrolysis rate [15]. The use of ultrasonication in the pretreatment of sludge improved the operational reliability of anaerobic digesters, decreased odor generation and clogging problems and enhanced sludge dewatering [16].

It must be noted that while $\mathrm{H}_{2} \mathrm{~S}$ has been accepted as the main odorous contaminant in biogas, recently bound proteins i.e., proteins loosely attached to the cell wall, have been determined as a major odor precursor downstream of anaerobic digestion, specifically during dewatering. Despite the numerous advantages of ultrasonic pretreatment of municipal biosolids, operational reliability, ease of 
implementation, elimination of odors and clogging, and good sludge dewaterability, the rapid wear on the sonotrode and negative energy balance [17] hindered widespread use of the technology.

The presence of high sulfate concentration in wastewater restricts the application of the anaerobic digestion treatment technology due to the production of the toxic and odorous hydrogen sulfide $\left(\mathrm{H}_{2} \mathrm{~S}\right)$ by sulfate-reducing bacteria [18]. The extensive ultrasonication research available in the open literature focused primarily on improving hydrolysis of municipal biosolids, with little or sparse data on applications to other wastes and impact on odor. Thus, the aim of this study is to investigate the effect of ultrasonication of hog manure on the performance of anaerobic digestion and its effect in odor reduction, specifically the removal of bound protein and hydrogen sulfide in the headspace.

\section{Experimental Section}

\subsection{Analytical methods}

Samples were analyzed for total suspended solids (TSS), volatile suspended solids (VSS), total Kjeldahl nitrogen (TKN), and soluble total Kjeldahl nitrogen (STKN) using standard methods [19]. Total and soluble chemical oxygen demand (TCOD, SCOD) and ammonia $\left(\mathrm{NH}_{4}-\mathrm{N}\right)$ were measured using $\mathrm{HACH}$ equipment (HACH Odyssey Analyzer and COD heating reactor) using standard HACH testing kits for different analyses. Soluble parameters were determined after filtering the samples through $0.45 \mu \mathrm{m}$ filter paper. The produced biogas was collected by wet tip (Gas meters for laboratories, Nashville, TN). The gas meter consists of a volumetric cell for gas-liquid displacement, a sensor device for liquid level detection, and an electronic control circuit for data processing and display (Speece, 1996) [20]. Biogas composition was determined by a gas chromatograph (Model 310 , SRI Instruments, Torrance, CA) equipped with a thermal conductivity detector (TCD) and a molecular sieve column (Molesieve 5A, mesh 80/100, $182.88 \times 0.3175 \mathrm{~cm}$ ). The temperatures of the column and the TCD detector were 90 and $105{ }^{\circ} \mathrm{C}$, respectively. Argon was used as carrier gas at a flowrate of $30 \mathrm{~mL} / \mathrm{min} . \mathrm{H}_{2} \mathrm{~S}$ was measured using the Odalog (model odalog type I, App-Tek International Pty Ltd, Brendale 4500, Australia), which has a detection range of 0-1000 ppm with an accuracy of 2 ppm. $\mathrm{SO}_{4}{ }^{2-}$ was measured using an ion chromatography (IC) system (Dionex 600, USA) equipped with CS16-HC and AS9- HC columns, respectively.

\subsection{Protein measurement}

Protein was determined by micro-bicinchoninic acid protein assay (Pierce, Rockford, USA), which was modified by Lowry et al. [21] using standard solution of bovine serum albumin. Cell protein was calculated as the difference between particulate and bound protein. In order to measure proteins, $50 \mathrm{~mL}$ samples were centrifuged at $10,000 \mathrm{rpm}$ for 15 minutes at $5{ }^{\circ} \mathrm{C}$ to separate the liquid and solids in the sample. The supernatant was filtered through a $1.5 \mu \mathrm{m}$ glass microfiber filter and the filtrate was analyzed for the soluble protein fraction. Bound protein was extracted from the suspended solids by mild $\mathrm{pH} 8$ phosphate buffers $(50 \mathrm{mM})$, while particulate protein representing both the bound protein adsorbed on biomass and the protein within the biomass was extracted by an alkaline $1 \mathrm{~N} \mathrm{NaOH}$ solution [21]. The solids from the filter were resuspended to a total volume of $50 \mathrm{~mL}$ with $\mathrm{pH} 8$ phosphate buffer $(50 \mathrm{mM})$ for measuring bound protein and $1 \mathrm{~N} \mathrm{NaOH}$ for particulate protein. The solution was mixed using a magnetic stirrer at $1500 \mathrm{rpm}$ for 10 minutes, and centrifuged at 10,000 rpm 
for 15 minutes at $5{ }^{\circ} \mathrm{C}$, with the centrate filtered through a $1.5 \mu \mathrm{m}$ glass microfiber filter, prior to protein analysis.

\subsection{Ultrasonication and anaerobic digestion set-up}

A lab scale ultrasonic probe was used to treat hog manure obtained from local hog farm in Southwestern, Ontario, Canada. The ultrasonic probe was supplied by Sonic and Materials (model VC-500, $500 \mathrm{~W}$, and $20 \mathrm{kHz}$ ). Hog manure was sonicated with specific energy inputs of $500 \mathrm{~kJ} / \mathrm{kgTS}$, with sonication pulses set to 2 seconds on and 2 seconds off to control the temperature rise of the sludge. Digestion of hog manure was carried out using anaerobic digester (10 L), with a working volume of $7.5 \mathrm{~L}$ and a solids retention time (SRT) of 15 days, operated in completely mixed continuous flow mode and maintained at constant temperature of $37{ }^{\circ} \mathrm{C}$. Table 1 lists the feed characteristics used for the unsonicated and sonicated runs. The digester was operated at steady-state, as reflected by constant specific biogas production rate and digester sludge biomass concentration (was reached after more than three turnovers of the mean SRT).

Table 1. Feed characteristics used for the unsonicated and sonicated manure.

\begin{tabular}{|c|c|c|c|}
\hline \multirow{2}{*}{$\begin{array}{c}\text { Parameter } \\
(\mathrm{mg} / \mathrm{L})\end{array}$} & \multirow{2}{*}{$\begin{array}{l}\text { Unsonicated manure } \\
\text { (influent to the } \\
\text { control digester) }\end{array}$} & \multicolumn{2}{|c|}{ Sonicated manure } \\
\hline & & $\begin{array}{l}\text { Manure before } \\
\text { sonication }\end{array}$ & $\begin{array}{l}\text { Manure after sonication } \\
\text { (influent to the digester) }\end{array}$ \\
\hline TSS & $15,119 \pm 552$ & $15,792 \pm 680$ & $13,916 \pm 785$ \\
\hline VSS & $11,000 \pm 526$ & $11,496 \pm 510$ & $8816 \pm 411$ \\
\hline TCOD & $26,638 \pm 1829$ & $28,000 \pm 1540$ & $28,333 \pm 1471$ \\
\hline SCOD & $12,645 \pm 1238$ & $13,050 \pm 1260$ & $15,854 \pm 1289$ \\
\hline Ammonia & $753 \pm 30$ & $824 \pm 88$ & $464 \pm 71$ \\
\hline P-Protein & $2671 \pm 87$ & $2854 \pm 210$ & $2569 \pm 183$ \\
\hline B-Protein & $675 \pm 73$ & $708 \pm 62$ & $623 \pm 76$ \\
\hline S-Protein & $2613 \pm 188$ & $2920 \pm 360$ & $3416 \pm 210$ \\
\hline TKN & $1779 \pm 89$ & $1879 \pm 98$ & $1800 \pm 107$ \\
\hline STKN & $939 \pm 108$ & $939 \pm 66$ & $1054 \pm 44$ \\
\hline VFA* & $1650 \pm 187$ & $1680 \pm 308$ & $1797 \pm 257$ \\
\hline
\end{tabular}

*VFA in $\mathrm{mgCOD} / \mathrm{L}$

\subsection{Specific energy input}

The specific energy input (SE) is a function of ultrasonic power, ultrasonic duration, and volume of sonicated sludge and TS concentration, and can be calculated using the following equation Bougrier et al. [22]:

$$
S E=\frac{P \times t}{V \times T S}
$$

where $S E$ is the specific energy input in $\mathrm{kWs} / \mathrm{kgTS}(\mathrm{kJ} / \mathrm{kgTS}), \mathrm{P}$ is the ultrasonic power in $\mathrm{kW}, \mathrm{t}$ is the ultrasonic duration in seconds, $\mathrm{V}$ is the volume of sonicated sludge in litres, and TS is the total solids concentration in $\mathrm{kg} / \mathrm{L}$. 


\section{Results and Discussion}

\subsection{Ultrasonication of hog manure}

Ultrasonication causes a localized pressure drop to below the evaporating pressure in the aqueous phase, resulting in the formation of micro bubbles by evaporation. The micro bubbles oscillate in sound field, grow by rectified diffusion and collapse in a non-linear manner. The combination of bubble oscillation and the resulting vacuum created by the collapse of the bubble leads to strong mechanical forces that can erode solid particles [23]. The hog manure was sonicated at a specific energy input of $500 \mathrm{~kJ} / \mathrm{kgTS}$. The characteristics of hog manure before and after ultrasonication are shown in Table 1. While there was no significant change in TCOD and TKN after ultrasonication, TSS, VSS, particulate protein and bound protein decreased by $17 \%, 21 \%, 10 \%$ and $12 \%$, respectively, after sonication. Furthermore, as expected, SCOD, VFA, ammonia, soluble protein and STKN increased by $29 \%, 12 \%, 17 \%, 17 \%$ and $12 \%$, respectively, after sonication. A paired t-test was conducted to evaluate the statistical significance of the observed differences as elaborated upon later.

\subsection{Solids destruction}

Figure 1 shows the steady-state average reductions of TSS, VSS, TCOD, and SCOD during AD for the unsonicated and sonicated manure. As shown in Figure 1, anaerobic VSS degradation efficiency of sonicated manure is higher than the unsonicated manure by $13 \%$ (51\% for sonicated versus $45 \%$ for unsonicated). However, considering the overall VSS removal efficiency of sonicated manure both during ultrasonication and digestion into consideration, there was a $36 \%$ increase in VSS removal efficiency due to sonication, with ultrasonication/AD achieving $61 \%$ versus $45 \%$ reduction for $\mathrm{AD}$ alone. This increase of VSS removal is consistent with the findings of Nickel and Neis [24], who observed an increase in VSS degradation of sonicated waste activated sludge (WAS) by $30 \%$ at an SRT of 16 days compared to the conventional digestion. In another study, Braguglia et al. [25] applied ultrasonication as a pretreatment for WAS at a specific energy of $5000 \mathrm{~kJ} / \mathrm{kgTS}$, and found that the VS removal increased only from $36 \%$ to $39 \%$ at SRT of 20 days, while at SRT of 10 days, the VS removal efficiency of untreated sludge declined from $36 \%$ to $31 \%$ and for sonicated sludge from $39 \%$ to $33 \%$ i.e., at both SRTs sonication affected a marginal 6-8\% increase in VS destruction efficiency.

Figure 1. Degradation efficiency of unsonicated and sonicated manure.

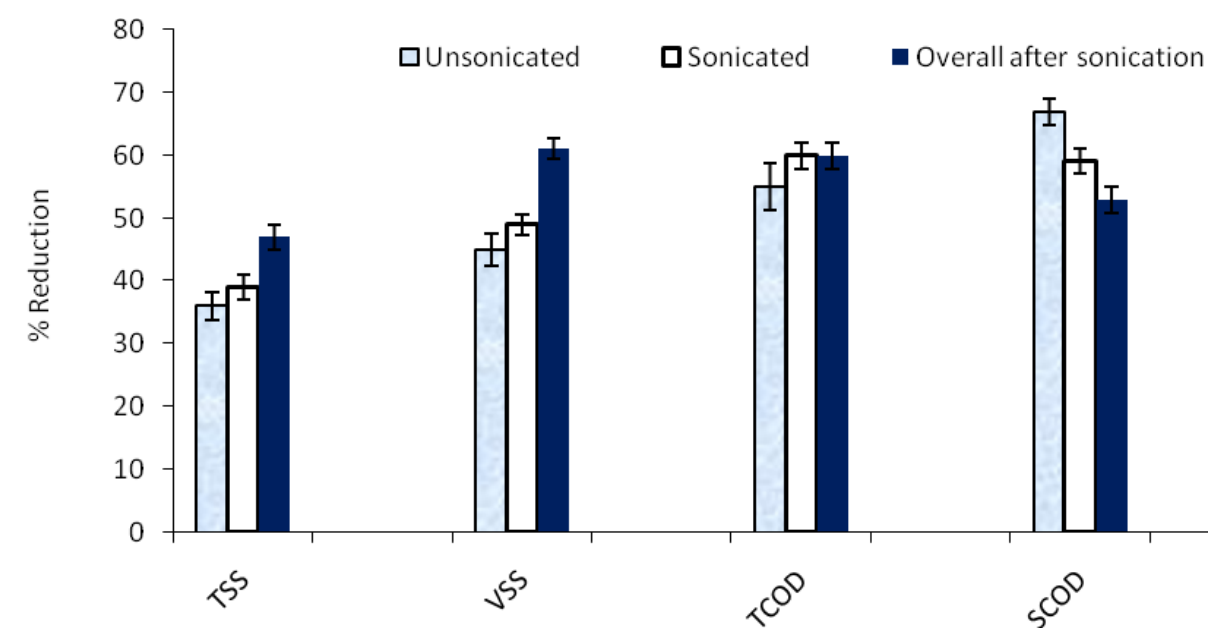


Tiehm et al. [10] applied ultrasonication in a pilot plant using a high performance ultrasound reactor $(3.6 \mathrm{~kW}, 31 \mathrm{kHz})$ for $64 \mathrm{sec}$ on a mixture of primary sludge and WAS (53\% primary sludge and $47 \%$ WAS) with average VSS of $25 \mathrm{~g} / \mathrm{kg}$, and observed a $10 \%$ increase in VS removal efficiency of sonicated waste over the conventional AD process at an SRT of 22 days, although no enhancement in VS reduction was observed at an SRT of 8 days. On the other hand, TSS removal efficiency in the digester increased from $36 \%$ to $43 \%$ with sonication, while the overall removal efficiency of TSS for sonicated manure was $47 \%$.

\subsection{COD destruction}

As expected, unsonicated and sonicated manure have approximately the same influent TCOD (less than $10 \%$ difference) while the SCOD for sonicated manure was higher than of the unsonicated manure by $34 \%$ (Table 1). After digestion, there was no significant difference in TCOD removal efficiency for the sonicated and unsonicated manure. TCOD removal efficiency was $55 \%$ and $60 \%$ for unsonicated and sonicated manure, respectively (Figure 1) due to a higher soluble fraction of COD in the influent. The relatively higher TCOD removal efficiency agrees with McDermott et al. [26], who applied ultrasonication on aquaculture waste (consisting predominantly of fecal material and waste fish food pellets) as a pretreatment to $\mathrm{AD}$ and reported COD removal efficiencies of $85 \%$ and $77 \%$ for sonicated and unsonicated waste, respectively.

In our case, the SCOD concentrations deceased from 12,645 to 4188 and from 13,050 to $6147 \mathrm{mg} / \mathrm{L}$ for unsonicated and sonicated hog manure during the anaerobic digestion. The SCOD removal efficiency in the digester receiving sonicated manure was $60 \%$ versus $67 \%$ for unsonicated manure, attributable to the high initial SCOD resulting from ultrasonication of manure, consistent with the observation of McDermott et al. [26] who reported no appreciable difference in reactor effluent SCOD values between the sonicated and unsonicated waste.

\subsection{Nitrogen compounds and odorous contaminants}

As depicted in Figure 2, the TKN after digestion decreased by $19 \%$ and $11 \%$ for sonicated and unsonicated manure, respectively to 1450 and $1582 \mathrm{mg} / \mathrm{L}$. STKN increased by $34 \%$ in the unsonicated manure after digestion to $1257 \mathrm{mg} / \mathrm{L}$, while STKN in the digested sonicated manure remained constant, potentially due to higher influent STKN due to ultrasonication. Ammonia exhibited the same trend of STKN in the reactor although it was below the inhibition level $(1500 \mathrm{mg} / \mathrm{L})$ in both cases. Digested manure ammonia concentration for unsonicated manure of $1200 \mathrm{mg} / \mathrm{L}$ was higher than the $980 \mathrm{mg} / \mathrm{L}$ for digested sonicated manure.

Proteins in sludge are usually divided into three types; particulate protein, bound protein, and soluble protein [27]. The particulate protein was considered as the tightly bound protein in flocs and is composed of particles in the bacterial cell mass, and the bound protein is the labile fraction loosely attached to biomass, while the soluble protein represents protein in the solution. Bound protein is considered to be one of the main causes for odor in anaerobic digestion [28]. 
Figure 2. Nitrogen compounds (TKN, STKN and ammonia) concentrations for sonicated and unsonicated manure.

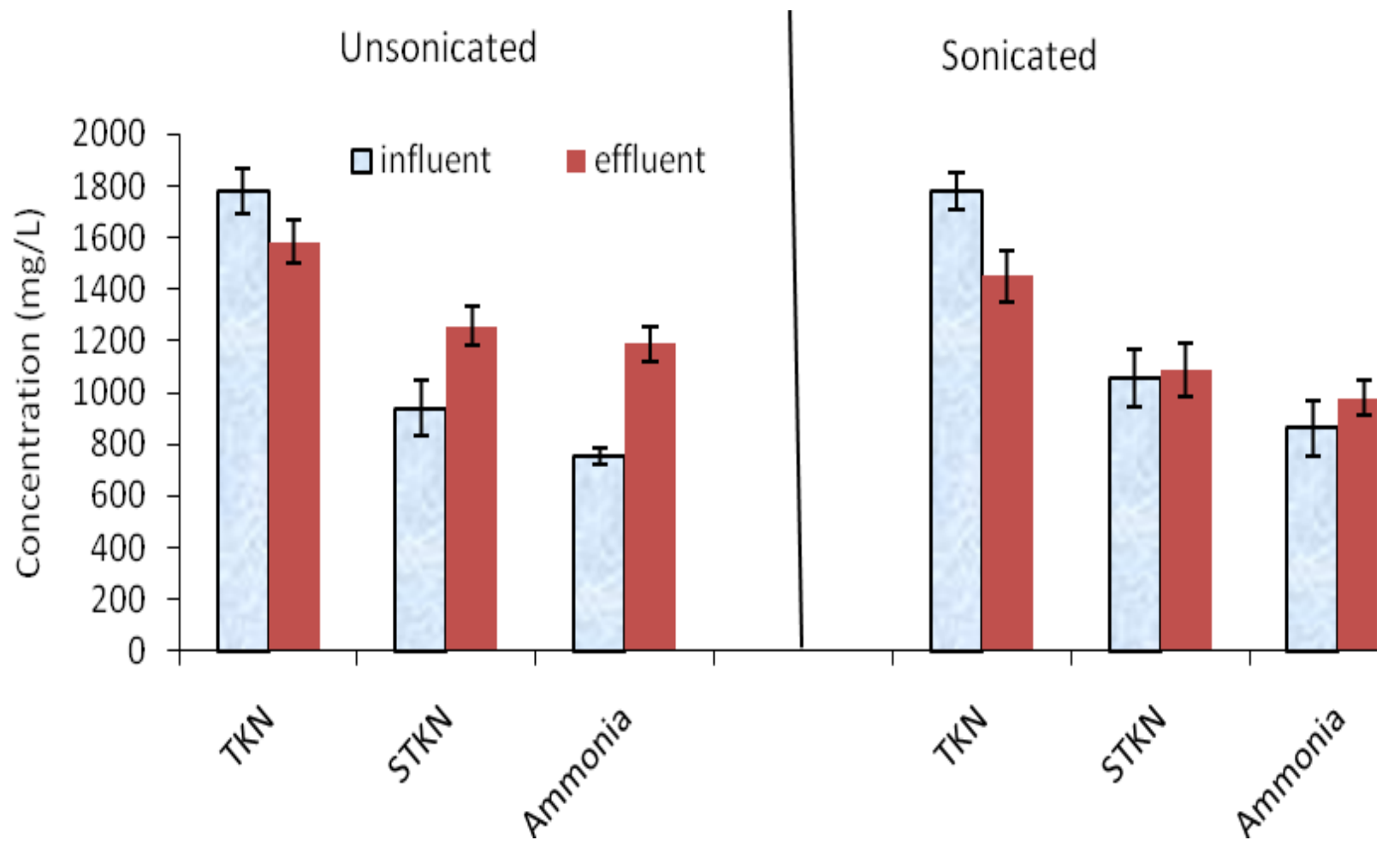

Figure 3 shows the removal efficiency of the three different types of proteins (particulate, bound and soluble) along with the sulphate reduction efficiency for the sonicated and unsonicated manure. During digestion, particulate protein removal efficiency averaged $58 \%$ and $60 \%$ for the unsonicated and sonicated manure, respectively, while the overall removal efficiency of particulate protein for the sonicated manure was $64 \%$. The digester removal efficiency of soluble protein for unsonicated manure of $75 \%$ was higher than the $65 \%$ for sonicated manure, and the overall efficiency of soluble protein for combined sonication and digestion was $59 \%$. This is due to the higher soluble protein concentration in the sonicated sludge due to the solubilization of the particulates. The enhancement of bound protein removal efficiency was highly discernible; a $13 \%$ increase in bound protein removal efficiency for sonicated manure during digestion relative to the unsonicated sludge, while the overall removal efficiency of bound protein for sonicated manure was higher than the unsonicated by $17.5 \%$ (Figure 2) which reflects the effect of ultrasonication on odor reduction caused by bound protein. In addition to the enhancement in bound protein reduction there was a decline in $\mathrm{H}_{2} \mathrm{~S}$ production in the digester headspace due to ultrasonication prior to digestion. The average concentration of $\mathrm{H}_{2} \mathrm{~S}$ in the headspace of the bioreactor deceased from 988 to 566 ppm for unsonicated and sonicated manure, respectively. The aforementioned reduction may reflect the effect of ultrasonication on sulfate reducing bacteria. Furthermore, $\mathrm{SO}_{4}{ }^{2-}$ reduction during anaerobic digestion was $59 \%$ and $38 \%$ for unsonicated and sonicated manure, respectively (Figure 3).

A theoretical estimation of the headspace $\mathrm{H}_{2} \mathrm{~S}$ concentration in the biogas was conducted using observed sulfate reduction of 11.4 and $25.4 \mathrm{mg} / \mathrm{L}$, for the sonicated and unsonicated manure with the measured values using the equation of Lens and Kuenen [29]:

$$
\mathrm{H}_{2}+\mathrm{SO}_{4}{ }^{2-} \rightarrow \mathrm{H}_{2} \mathrm{~S}+\mathrm{HS}^{-}+5 \mathrm{H}_{2} \mathrm{O}+3 \mathrm{OH}^{-}
$$


Figure 3. Degradation efficiency of particulate protein, bound protein, soluble protein and sulfate.

- Unsonicated $\quad$ Q Overall after sonication

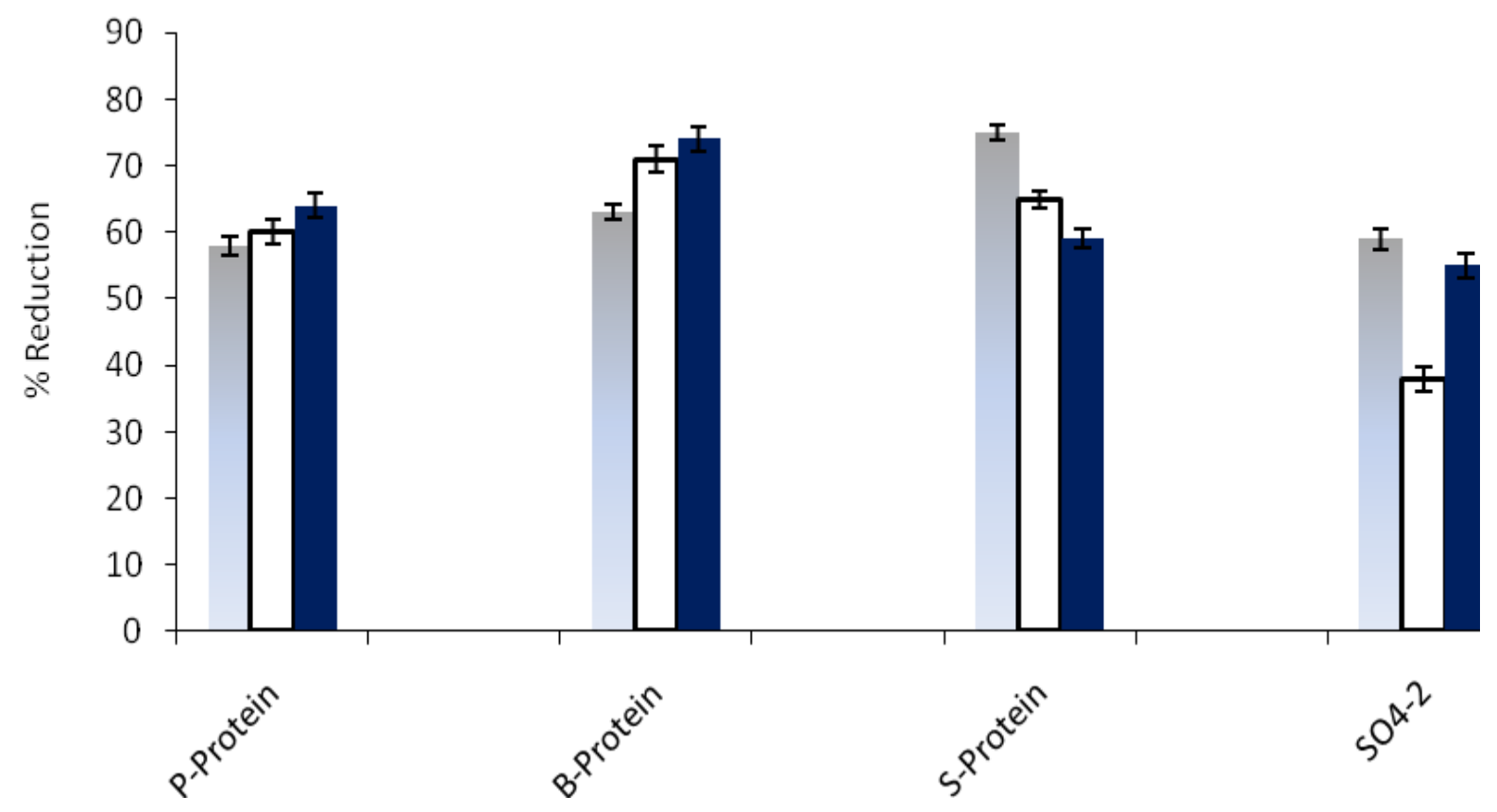

Henry's constant for $\mathrm{H}_{2} \mathrm{~S}$ of 9.8 atm $\mathrm{L} / \mathrm{mol} \mathrm{K}$ at $25{ }^{\circ} \mathrm{C}$ [30] was corrected for the operating temperature of $37{ }^{\circ} \mathrm{C}$. The calculated $\mathrm{H}_{2} \mathrm{~S}$ concentrations in both the sonicated and unsonicated manures of 494 and 954 ppm, respectively, are 13\% and 4\% lower than the observed 566 and 998 ppm, indicated a good mass balance in the system.

A statistical-paired t-test used to evaluate the observed differences in parameter reduction during anaerobic digestion between the sonicated and unsonicated manures, revealed that TSS, VSS, TCOD, bound protein, soluble protein and $\mathrm{H}_{2} \mathrm{~S}$ efficiencies were statistically different at the $95 \%$ confidence level with only SCOD and particulate protein insignificant at the 95\% confidence level. Thus, it is evident that ultrasonication has achieved significant improvement of odor compounds (particularly bound protein and $\mathrm{H}_{2} \mathrm{~S}$ in the headspace).

\subsection{Biogas production}

One of the most evident differences between sonicated and unsonicated manure was biogas production. Figure $4 \mathrm{a}$ shows the measured and theoretical methane (calculated as $0.4 \mathrm{~L} / \mathrm{g}$ COD consumed) for the unsonicated and sonicated hog manure. As can be seen from the Figure, the methane production rate for the digester at an SRT of 15 days increased from $2.5 \mathrm{~L} / \mathrm{d}$ in the unsonicated manure to $3.0 \mathrm{~L} / \mathrm{d}$ for the sonicated manure, concomitant with a marginal increase in methane content from $53 \%$ to $56 \%$. Figure $4 \mathrm{~b}$ shows the cumulative methane production for sonicated and unsonicated manure, the maximum volumetric methane production rate increasing from $0.34 \mathrm{~L}_{\mathrm{CH} 4} / \mathrm{L}_{\mathrm{r}} \cdot \mathrm{d}$ in the unsonicated manure to $0.39 \mathrm{~L}_{\mathrm{CH} 4} / \mathrm{L}_{\mathrm{r}} \cdot \mathrm{d}$ for the sonicated manure. 


\subsection{BioWin model}

BioWin (EnviroSim Associates, Flamborough, Ontario, Canada) was used to study the performance of anaerobic digestion of sonicated and unsonicated manures at different SRTs. The experimental data for the two runs (sonicated and unsonicated) were used to calibrate the model. Table 2 summarizes the model output for the calibration runs. As depicted in Table 2, the effluent characteristics were mostly in the range of measured average and standard deviations for both manures.

Figure 4. (a) Measured and theoretical methane production for unsonicated and sonicated hog manure. (b) Cumulative methane productions for unsonicated and sonicated hog manure.
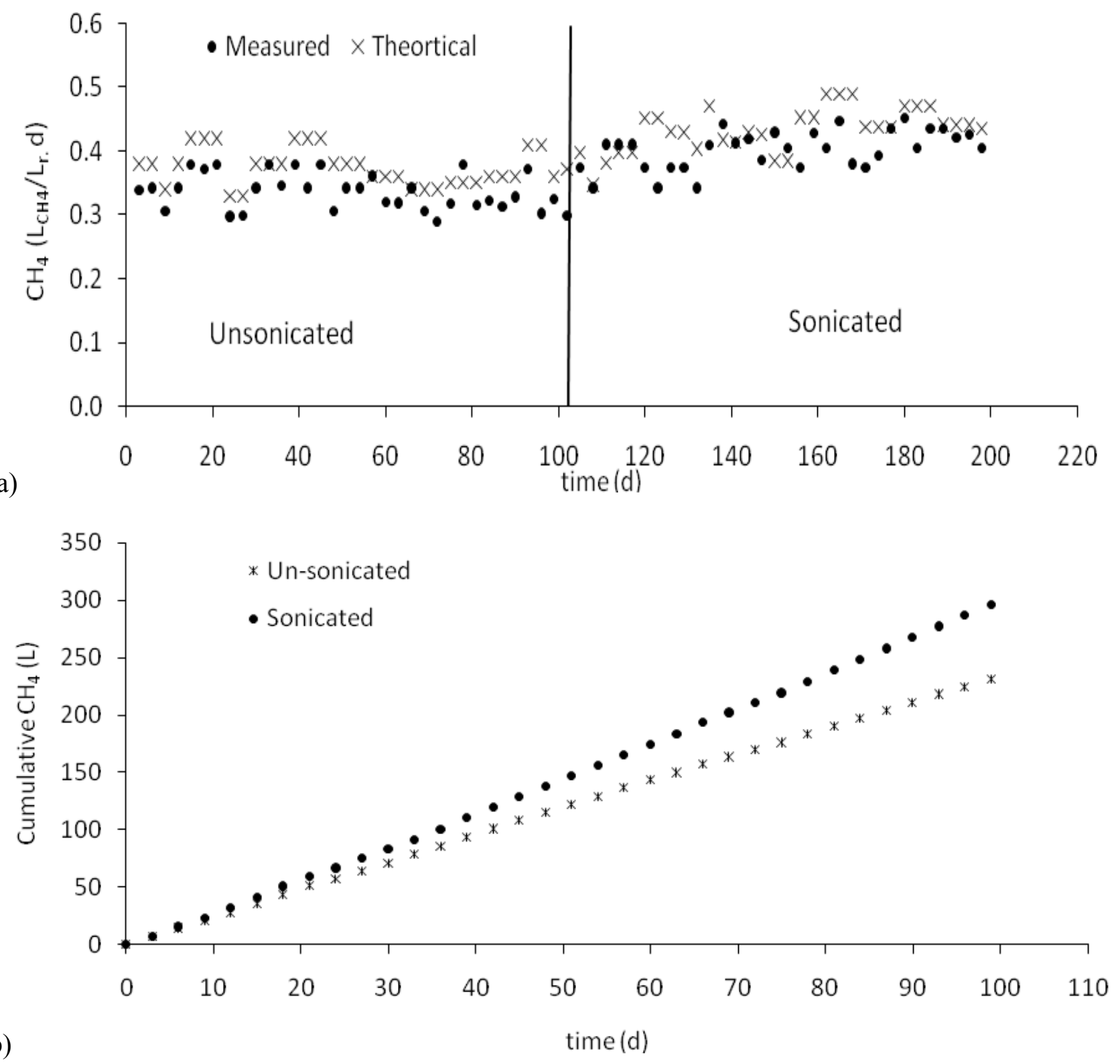

Based on the comparison of the simulated and measured digested sludge characteristics listed in Table 2, the deviations for the unsonicated manure TSS, VSS, TCOD, SCOD, ammonia, TKN, STKN, acetic acid plus propionic acid, and daily methane production rate are $0.6 \%, 7.6 \%, 10.9 \%, 3.6 \%, 4.9 \%$, $7.2 \%, 6.9 \%, 0.7$ and $2.8 \%$, respectively. The corresponding values for the sonicated manure are $7.9 \%$, $6.1 \%, 9 \%, 3.5 \%, 22.6 \%, 0.2 \%, 14 \%, 19.8 \%$ and $3.3 \%$. It is thus evident that the model default kinetic 
coefficients and stoichiometric parameters fit the data very well, and the effect of ultrasonication pretreatment did not change the main biochemical reactions in the anaerobic digestion significantly. Following the successful model calibration, the same influent characteristics of both raw manure and sonicated manure were used to study the effect of SRT on VSS destruction efficiency and biogas production rate. Table 3 clearly indicates that at shorter SRTs, VSS destruction efficiencies for sonicated manure were less than the unsonicated manure despite higher methane production. However, interestingly the improvement in VSS destruction efficiencies during anaerobic digestion by sonication becomes apparent at longer SRTs. At an SRT of 3 days, while the model predicts $30 \%$ more methane in digestion of sonicated manure relative to unsonicated, VSS destruction efficiencies for sonicated manure is only $60 \%$ of that for unsonicated manure. However at SRT of 30 days, a $20 \%$ increase in methane production was projected for anaerobic digestion of sonicated manure relative to the unsonicated manure, in close agreement with the $22 \%$ increase in VSS destruction efficiencies.

\subsection{Economic analysis}

Table 4 shows the economic evaluation of ultrasonication pretreatment. Unit costs for dewatering and transportation, methane, and electrical energy used in the economic evaluation are $\$ 250 /$ ton dry solids, $\$ 0.28 / \mathrm{m}^{3} \mathrm{CH}_{4}$, and $\$ 0.07 / \mathrm{kWh}$. Using the specific sonication energy of $500 \mathrm{~kJ} / \mathrm{kgTS}$, the cost of sonication translates to $\$ 9.7 /$ ton dry solids. The net benefit was calculated as the difference between the costs of methane price minus dewatering minus pretreatment (i.e., sonication) for the manure. It is interesting to note that the net benefit increases sharply initially and stabilizes at $\$ 42-49$ /ton dry solids for SRTs of 15 to 30 days. The net benefit was most sensitive to methane production. The aforementioned discernible observation appears to be counter intuitive since logically the impact of pretreatment should have been more pronounced on heavily loaded digesters. 
Table 2. Measured and simulated data using BioWin software.

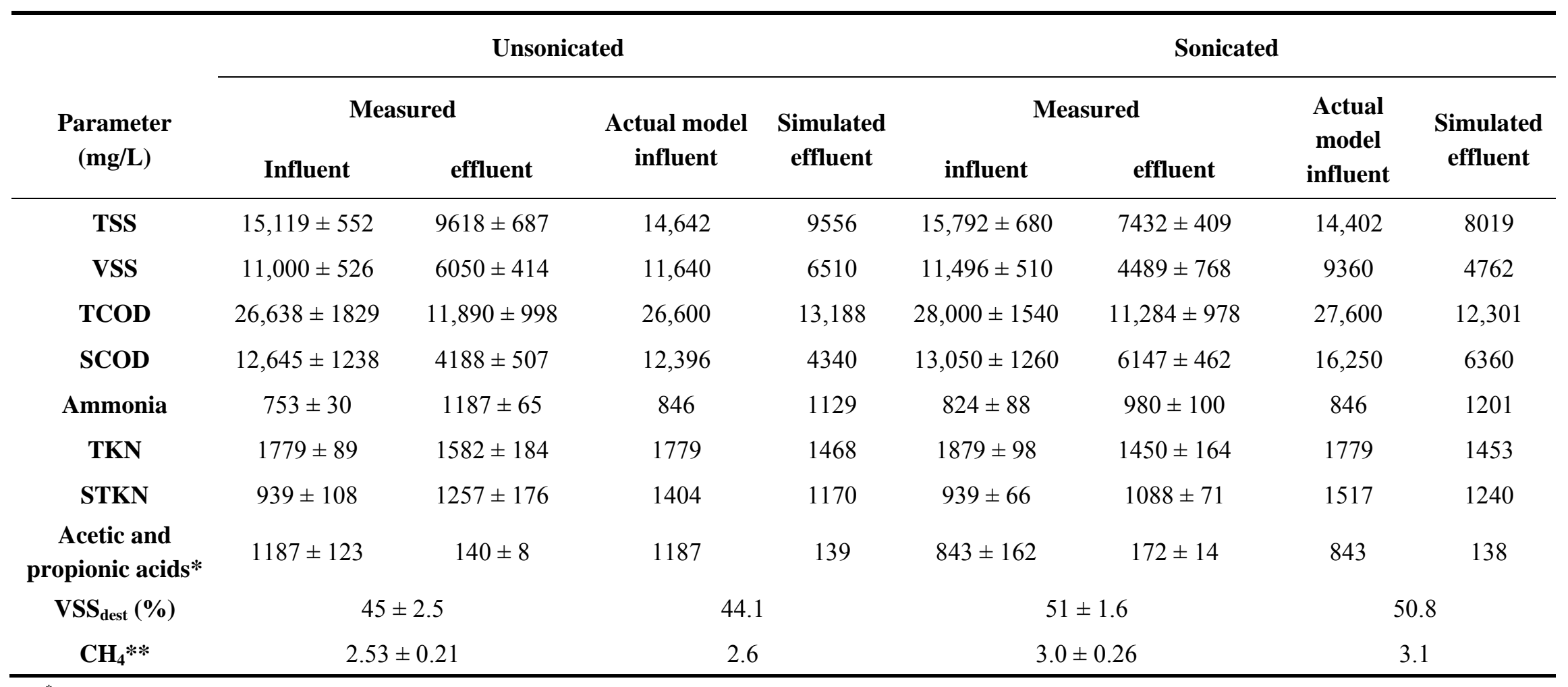

${ }^{*}$ Acetic and propionic acids in $(\mathrm{mgCOD} / \mathrm{L})$

${ }^{* *} \mathrm{CH}_{4}$ in (L/d) 
Table 3. VSS destruction and methane production at different SRTs using BioWin software.

\begin{tabular}{ccccc}
\hline \multirow{2}{*}{ SRT (d) } & \multicolumn{2}{c}{ Unsonicated manure } & \multicolumn{2}{c}{ Sonicated manure } \\
& VSS destruction (\%) & $\mathbf{C H}_{\mathbf{4}} \mathbf{( L / d )}$ & VSS destruction (\%) & $\mathbf{C H}_{\mathbf{4}} \mathbf{( L / d )}$ \\
\hline 3 & 21 & 3.0 & 13.2 & 3.9 \\
5 & 26 & 6.0 & 22 & 7.0 \\
7.5 & 32.9 & 4.5 & 33.2 & 5.4 \\
10 & 37.8 & 3.6 & 40.9 & 4.3 \\
15 & 44.1 & 2.6 & 50.8 & 3.1 \\
20 & 48 & 2.0 & 56.9 & 2.5 \\
25 & 50.6 & 1.7 & 61.1 & 2.0 \\
30 & 52.5 & 1.4 & 64.1 & 1.7 \\
\hline
\end{tabular}

Table 4. Economical study calculation based on ton dry solids influent.

\begin{tabular}{|c|c|c|c|c|c|c|c|c|c|}
\hline \multirow{3}{*}{$\begin{array}{l}\text { SRT } \\
\text { (d) }\end{array}$} & \multicolumn{4}{|c|}{ Unsonicated manure } & \multicolumn{4}{|c|}{ Sonicated manure } & \multirow{3}{*}{$\begin{array}{c}\text { Net* }^{*} \\
\$\end{array}$} \\
\hline & \multicolumn{2}{|c|}{$\begin{array}{l}\text { Energy in } \\
\text { Dewatering }\end{array}$} & \multicolumn{2}{|c|}{$\begin{array}{c}\text { Energy out } \\
\text { Gas }\end{array}$} & \multicolumn{2}{|c|}{$\begin{array}{l}\text { Energy in } \\
\text { dewatering }\end{array}$} & \multicolumn{2}{|c|}{$\begin{array}{l}\text { Energy out } \\
\text { Gas }\end{array}$} & \\
\hline & $\begin{array}{c}\text { wt of sludge } \\
\text { after treatment (ton) }\end{array}$ & $\begin{array}{c}\$ \text { for dewatering } \\
\text { and transportation }\end{array}$ & $\begin{array}{l}\mathrm{CH}_{4} \\
\left(\mathbf{m}^{3}\right)\end{array}$ & $\begin{array}{c}\$ \text { from } \\
\mathrm{CH}_{4}\end{array}$ & $\begin{array}{c}\text { wt of sludge } \\
\text { after treatment (ton) }\end{array}$ & $\begin{array}{c}\$ \text { for dewatering } \\
\text { and transportation }\end{array}$ & $\begin{array}{l}\mathrm{CH}_{4} \\
\left(\mathbf{m}^{3}\right) \\
\end{array}$ & $\begin{array}{c}\$ \text { from } \\
\mathrm{CH} 4\end{array}$ & \\
\hline 3 & 0.87 & 218 & 80 & 22 & 0.80 & 199 & 112 & 31 & 18 \\
\hline 5 & 0.83 & 207 & 267 & 75 & 0.74 & 186 & 335 & 94 & 31 \\
\hline 7.5 & 0.76 & 191 & 300 & 84 & 0.68 & 169 & 383 & 107 & 36 \\
\hline 10 & 0.72 & 180 & 320 & 90 & 0.63 & 157 & 411 & 115 & 39 \\
\hline 15 & 0.66 & 165 & 347 & 97 & 0.57 & 141 & 445 & 125 & 42 \\
\hline 20 & 0.63 & 156 & 356 & 100 & 0.53 & 132 & 467 & 131 & 46 \\
\hline 25 & 0.60 & 150 & 378 & 106 & 0.50 & 125 & 482 & 135 & 44 \\
\hline 30 & 0.58 & 146 & 373 & 105 & 0.48 & 121 & 492 & 138 & 49 \\
\hline
\end{tabular}

*Net $\$=\left[\$ \text { from } \mathrm{CH}_{4}-\$ \text { for ultrasonication }-\$ \text { for dewatering and transportation }\right]_{\text {sonicated manure }}-\left[\$ \text { from } \mathrm{CH}_{4}-\$ \text { for dewatering and transportation }\right]_{\text {unsonicated manure }}$ 


\section{Conclusions}

Based on the finding of this study, the following conclusions can be drawn:

- The overall TSS and VSS removal efficiencies of sonicated manure were higher than the unsonicated manure by $36 \%$ and $31 \%$, respectively.

- There was no significant difference in TCOD removal efficiency for the sonicated and unsonicated manure during anaerobic digestion, while the SCOD removal efficiency in the digester receiving sonicated manure was lower than that receiving the unsonicated manure.

- There was no significant difference in particulate protein removal efficiency for the sonicated and unsonicated manure in the anaerobic digester, whereas the overall removal efficiency was slightly increased (by 10\%) for sonicated manure.

- The overall removal efficiency of bound protein for sonicated manure was higher than the unsonicated manure by $17.5 \%$.

- The concentration of $\mathrm{H}_{2} \mathrm{~S}$ in the headspace of the bioreactor decreased from $988 \mathrm{ppm}$ in the unsonicated manure digester to $566 \mathrm{ppm}$ for sonicated manure digester, respectively.

- The effluent ammonia for digested unsonicated manure $(1200 \mathrm{mg} / \mathrm{L})$ was higher than that of sonicated manure $(980 \mathrm{mg} / \mathrm{L})$.

- The methane production rate increased from $0.34 \mathrm{~L}_{\mathrm{CH}} / \mathrm{L}_{\mathrm{r}} \cdot \mathrm{d}$ for the unsonicated manure to 0.39 $\mathrm{L}_{\mathrm{CH} 4} / \mathrm{L}_{\mathrm{r}} \cdot \mathrm{d}$ for the sonicated one.

- BioWin simulations indicated that at shorter SRTs, VSS destruction efficiencies for sonicated manure were less than the unsonicated manure despite higher methane production. However, interestingly the improvement in VSS destruction efficiencies during anaerobic digestion by sonication becomes apparent at SRTs around 15-30 days, which are commonly used SRTs for anaerobic digestion of biosolids in full scale.

- The net cost benefit of ultrasonication, calculated as the difference between the cost of methane output minus cost of energy input (only for ultrasonication) minus the cost of biosolids dewatering and disposal for the sonicated and unsonicated manure, increases sharply initially and stabilizes at \$42-49/ton dry solids for SRTs of 15 to 30 days.

\section{Acknowledgements}

Authors want to thank Trojan Technologies, Canada and Egyptian Ministry of Higher Education for their financial contributions.

\section{References}

1. Van Velsen, A.F.M. Anaerobic digestion of swine waste. Neth. J. Agric. Sci. 1979, 27, 142-152.

2. Andreadakis, A.D. Anaerobic digestion of swine waste. Water Sci. Technol. 1992, 25, 9-16.

3. Lo, K.V.; Liao, P.H.; Gao, Y.C. Anaerobic treatment of swine wastewater using hybrid UASB reactors. Bioresour. Technol. 1994, 47, 153-157.

4. Sanchez, E.; Borja, R.; Weiland, P.; Travieso, L.; Martin, A. Effect of substrate concentration and temperature on the anaerobic digestion of piggery waste in a tropical climate. Proc. Biochem. 2001, 37, 483-489. 
5. Pfeffer, J.T. Anaerobic digestion process. In Proceedings of the First Int. Symp. On Anaerobic Digestion, University College, Cardiff, Wales, UK, 1979.

6. Eastman, J.A. Ferguson J.F. Solublisation of particulate organic carbon during the acid phase of anaerobic digestion. J. Wat. Poll. Cont. Fed. 1981, 53, 352-365.

7. Parkin, G.F.; Owen, W.F. The fundamentals of anaerobic digestion of wastewater sludge. J. Environ. Engineer. 1986, 112, 867-920.

8. Wang, Q.; Noguchi, C.; Hara, Y.; Sharon, C.; Kakimoto, K.; Kato, Y. Studies on anaerobic digestion mechanism: Influence of pretreatment temperature on biodegradation of waste activated sludge. Environ. Technol. 1997, 18, 999-1008.

9. González-Fernández, C.; León-Cofreces, C.; García-Encina, P.A. Different pretreatments for increasing the anaerobic biodegradability in swine manure. Bioresour. Technol. 2008, 99, 8710-8714.

10. Tiehm, A.; Nickel, K.; Nies, U. The use of ultrasound to accelerate the anaerobic digestion of sewage sludge. Water Sci. Technol. 1997, 36, 121-128.

11. Wang, Q.; Kuninobu, M.; Kakimoto, K.; Ogawa, H.I.; Kato, Y. Upgrading of anaerobic digestion of waste activated biosolid by ultrasonic pretreatment. Bioresour. Technol. 1999, 68, 309-313.

12. Tiehm, A.; Nickel, K.; Zellhorn, M.; Neis, U. Ultrasonic waste activated biosolid disintegration for improving anaerobic stabilization. Water Res. 2001, 35, 2003-2009.

13. Neyens, E.; Baeyens, J.; Dewil, R.; De Heyder, B. Advanced biosolid treatment affects extracellular polymeric substances to improve activated biosolid dewatering. J. Hazard. Mater. 2004, 106, 83-92.

14. Lawler, D.F.; Chung, Y.J.; Hwang, S.J.; Hull, B.A. Anaerobic digestion: Effects on particle size and dewaterability. J. Water Pollut. Control Fed. 1986, 58, 1107-1117.

15. Quarmby, J.; Scott, J.R.; Mason, A.K.; Davies, G.; Parsons, S.A. The application of ultrasound as a pretreatment for anaerobic digestion. Environ. Technol. 1999, 20, 1155-1161.

16. Pérez-Elvira, S.I.; Nieto-Diez, P.; Fdz-Polanco, F. Sludge minimisation technologies. Review Environ. Sci. Bio-Technol. 2006, 5, 375-398.

17. Stukey, D.C.; McCarthy, P.L. Thermochemical pretreatment of nitrogenous materials to increase methane yield. Biotechnol. Bioeng. Symp. 1978, 8, 219-233.

18. Lens, P.; Visser, A.; Janssen, A.; Pol, L.; Lettinga, G. Biotechnological treatment of sulfate-rich wastewaters. Critic. Review Environ. Sci. Technol. 1998, 28, 41-88.

19. APHA, Standard Methods for the Examination of Water and Wastewater, 20th Edition; American Public Health Association: Washington DC, USA, 1998.

20. Speece, R.E., Anaerobic Biotechnology for Industrial Waste Waters; Archae Press: Nashville, TN, USA, 1996.

21. Lowry, O.H.; Rosebrough, N.J.; Farr, A.L.; Randall, R.J. Protein measurements with the folin phenol reagent. J. Biol. Chem. 1951, 193, 265-275.

22. Bougrier, C.; Carrère, H.; Delgenès, J.P. Solubilisation of waste-activated sludge by ultrasonic treatment. Chem. Eng. J. 2005, 106, 163-169.

23. Tiehm, A.; Nickel, K.; Nies, U. The use of ultrasound to accelerate the anaerobic digestion of sewage sludge. Water Sci. Technol. 1997, 36, 121-128. 
24. Nickel, K.; Neis, U. Ultrasonic disintegration of biosolids for improved biodegradation. Ultrason. Sonochem. 2007, 14, 450-455.

25. Braguglia, C.M.; Mininni, G.; Gianico, A. Is sonication effective to improve biogas production and solids reduction in excess sludge digestion? Water sci. Technol. 2008, 57, 479-483.

26. McDermott, B.L.; Chalmer, A.D.; Goodwin, J.A. Ultrasonication as a pre-treatment method for the enhancement of the psychrophilic anaerobic digestion of aquaculture effluents. Environ. Technol. 2001, 22, 823-830.

27. Dimock, R.; Morgenroth, E. The influence of particle size on microbial hydrolysis of protein particles in activated sludge. Water Res. 2006, 40, 2064-2074.

28. Higgins, M.; Glindemann, D.; Novak, J.T.; Murthy, S.N.; Gerwin, S.; Forbes, R. Standardized biosolid incubation, headspace odor measurement and odor production consumption cycles. In Proceedings of the Water Env. Federation and AWWA Odors and Air Emissions Conference, Bellevue, Washington, April 2004.

29. Lens, P.N.L.; Kuenen, J.G. The biological sulfur cycle: New opportunities for environmental biotechnology. Water Sci. Technol. 2001, 44, 57-66.

30. Stumm, W.; Morgan, J.J. Aquatic Chemistry: An Introduction Emphasizing Chemical Equilibria in Natural Waters, 2nd Edition; John Wiley \& Sons: New York, NY, USA, 1981.

(C) 2010 by the authors; licensee MDPI, Basel, Switzerland. This article is an Open Access article distributed under the terms and conditions of the Creative Commons Attribution license (http://creativecommons.org/licenses/by/3.0/). 